\title{
Phylogenetic Analysis Based on 16S rRNA Gene of a Thermophilic Protease-Secreting Bacillus gelatini-TPNK-3 Isolate from Kiteezi Landfill, Uganda
}

\author{
JOHN OMARA, TOBIUS P. EKEYA and JOSEPH F. HAWUMBA* \\ Department of Biochemistry, Makerere University, P.O. Box 7062, Kampala, Uganda \\ Received 6 April 2012, revised 11 June 2012, accepted 4 July 2012
}

\begin{abstract}
A thermophilic protease-secreting bacterial isolate, TPNK-3, from Kiteezi landfill, is an aerobic Gram-positive spore-forming bacterium with rod-shaped cells $\left(3.28 \mu \mathrm{m}\right.$ long and $0.45 \mu \mathrm{m}$ wide). Optimal growth was observed at $55^{\circ} \mathrm{C}$ and $\mathrm{pH}$ of 7.0 , and the isolate tolerates up to $5 \%(\mathrm{w} / \mathrm{v}) \mathrm{NaCl}$, exhibits extracellular amylolytic, cellulolytic and caseinolytic activities, utilizes a range of carbon and nitrogen sources and has a GC content of $45 \mathrm{~mol} \%$. The $16 \mathrm{~S}$ rRNA gene sequence analysis showed that the studied bacterium belongs to the genus Bacillus, and closest to Bacillus gelatini (>99.9\%). Consequently, isolate TPNK3 is tentatively described as Bacillus gelatini strain TPNK3.
\end{abstract}

Ke y words: 16 S rRNA-gene, phylogenetic relationship, thermophilic

Phylogenetic methods based on the sequencing and cataloguing of rRNAs (16S and 23S), have played a major role in modern taxonomic and phylogenetic studies of newly isolated microorganisms. Typically, the analyses of $16 \mathrm{~S}$ rRNA gene sequences are generally used as a framework for bacterial classification (De Clerck et al., 2004) and both archaeal and bacterial domains have been phylogenetically described using rRNA-based methods. For instance, analysis based on $16 \mathrm{~S}$ rRNA has been used in multiple studies such as (i) characterization of the Ehrlichia canis strains involved in naturally occurring canine monocytic ehrlichiosis (CME) and to investigate the differences between the 16S rRNA genes of Ehrlichia canis responsive to mild non-myelosuppressive and severe myelosuppressive forms of CME (Siarkou et al., 2007); (ii) establishing the genotypic diversity among marine Bacillus species (Ki et al., 2009); (iii) establishing phylogenetic relationships between hydantoinase-producing bacteria (Mei et al., 2009); and (iv) differentiation the species in the genus Anaplasma in China (Liu et al., 2005). Furthermore, the strength of the rRNA sequencing approach has been illustrated in its application to the phylogenetic placement of unculturable microorganisms (Nogales et al., 2001). Thermophilic organisms are promising sources of thermostable enzymes. Since these enzymes tend to remain stable under harsh industrial conditions, they are used in a number of biotechnological bioprocesses (Jaenicke et al., 1996). For instance, as components of laundry detergents, in the bioconversion of waste into biomass, leather tanning, dairy and food processing, aerobic digestion of sewerage sludge and pharmaceutical industries (Genckal and Tari, 2006; Liu et al., 2011). The wide use of thermostable enzymes in the industry prompts multiple screens of environments that can contain bacteria producing such enzymes.

In our study, we screened Kiteezi landfill site in search for bacterial isolates that can produce thermostable enzymes. The sampling site encompasses an area of four acres of which three contained freshly damped municipal solid waste. Thirty (30) soil samples of approximately $200 \mathrm{~g}$ each were collected from the depth of at least two feet where we noted temperature above $50^{\circ} \mathrm{C}$. Samples were collected from freshly damped decomposing garbage and suspended in two volumes of sterile distilled water. After agitation for $30 \mathrm{~min}$ to achieve thorough mixing, the samples were serially diluted and plated onto casein agar ( $\mathrm{pH} 7.5)$ then incubated at $55^{\circ} \mathrm{C}$ for $48 \mathrm{~h}$.

The standard medium for routine growth of the studied isolate was prepared as describe previously (Hawumba et al., 2001). Casein medium, which was

* Corresponding author: J.F. Hawumba Department of Biochemistry and Sports Science, P.O. Box 7062, Kampala, Uganda; phone: 256-414-530555 (W), 256-712-431586 (Mobile); fax. 256-414-531061; e-mail: jhawumba@sci.mak.ac.ug or jfh69fuuna@gmail.com 
used in the production of crude enzyme solution, was prepared by modifying the standard medium by replacement of the peptone with casein at $2 \%(\mathrm{w} / \mathrm{v})$. To investigate the utilization various individual carbon and nitrogen substrates as sole carbon and nitrogen sources, respectively, the standard medium was modified by supplying: (a) the carbon substrates (i.e. L-sorbose, sorbitol, L-arabinose, D-fructose, D-arabinose, D-xylose, inulin, D (+) maltose, mannitol, D-galactose, dextrin, inositol, cellobiose, starch, cellulose, sodium acetate, sodium malonate, sodium oxalate, sodium succinate, and sodium malate) and (b) nitrogen substrates (D and L-serine, L-asparagine, D and L-phenylalanine, D and L-valine, L-glutamate, D and L-tyrosine, L-cysteine, glycine, L-aspartic acid, L-tryptophan, L-arginine, D and L-histidine, D-alanine, D-methionine, $\mathrm{D}$ and L-leucine, L-tyrosine, urea, and $\mathrm{D}$ and L-ornithine). To solidify the media, $1.5 \%(\mathrm{w} / \mathrm{v})$ of agar was added to the broth. The $\mathrm{pH}$ was adjusted to $\mathrm{pH} 7.5$ using $2 \mathrm{~N} \mathrm{NaOH}$ or $1 \mathrm{~N} \mathrm{HCl}$ before autoclaving at $121^{\circ} \mathrm{C}$ for 25 minutes.

To isolate pure cultures, individual colonies which produced clear zones of hydrolysis were purified by repeated streaking on the standard medium and finally on the casein agar medium. Four isolates exhibiting extracellular caseinolytic activity were identified and designated as: TPNK1, TPNK2, TPNK3 and TPNK4. Isolate TPNK3, producing the largest hydrolysis zone around its colonies, was selected for further characterization. The optimal $\mathrm{pH}$ for growth of each isolate was determined in $50 \mathrm{ml}$ of the medium buffered with $10 \mathrm{mM}$ benzoic acid at $\mathrm{pH} 4,10 \mathrm{mM}$ pyridine at $\mathrm{pH}$ $5,10 \mathrm{mM}$ phosphate buffer at pH 6 and $10 \mathrm{mM}$ Tris$\mathrm{HCl}$ at $\mathrm{pH} 7$ to 9. The optimal growth temperature was determined by culturing the isolate in $100 \mathrm{ml}$ of standard medium at temperatures: $40,45,50,55,60$, and $65^{\circ} \mathrm{C}$, respectively, at optimal $\mathrm{pH}$, bacterial growth was monitored by measuring optical density at $600 \mathrm{~nm}$ every $30 \mathrm{~min}$ for $10 \mathrm{~h}$. At each investigated temperature, the growth rate $(\mu)$ was calculated for the period of exponential increase. The ability of isolate TPNK3 to utilize various substrates as sole carbon and nitrogen sources, respectively, was investigated. The medium was individually supplied with appropriate substrates and cultured at optimal conditions of temperature and $\mathrm{pH}$. Catalase activity was examined upon addition of 3\% $\mathrm{H}_{2} \mathrm{O}_{2}$, appearance of gas bubbles was considered a positive test for catalase activity.

TPNK3 isolate grew at $\mathrm{pH}$ from 5.8 to 8.2 , with an optimum $\mathrm{pH}$ of 7.0 . The growth rate was determined at optimal $\mathrm{pH}$ within the temperature range of 40 to $65^{\circ} \mathrm{C}$. Maximum growth rate was observed at $55^{\circ} \mathrm{C}$ and no growth occurred above 65 and below $40^{\circ} \mathrm{C}$, respectively. At the optimal growth temperature and optimal $\mathrm{pH}$, the generation time was $35 \mathrm{~min}$. Isolate TPNK3 is also halotolerant and could grow in broth containing
5\% (w/v) NaCl. However, no growth occurred above this value. The catalase test revealed that the isolate is either aerobic or facultatively anaerobic.

Genomic DNA was isolated as described previously (Hawumba et al., 2001). The mol \% G+C was determined by method of Owen and Hill (1979). The gene encoding 16S rRNA was amplified using the universal primers fD1 and rP2 (Weisburg et al., 1991) and its nucleotide sequence was determined by automated sequencing with an ABI PRISM ${ }^{\mathrm{TM}}$ BigDye $^{\mathrm{TM}}$ Terminator Cycle Sequencing Ready Reaction mixture (Perkin-Elmer Applied Biosystems, Foster City, CA USA), in a Hitachi 3100 capillary array automated DNA sequencer. The resulting sequence was edited to a total length of 1350 nucleotides. A BLAST search of the GenBank database of the National Center for Biotechnology Information, (www.ncbi.nlm.nih.gov/GenBank) retrieved several sequences that were compared with that of TPNK3. These sequences were edited using the BioEdit program and the phylogenetic relationship of isolates TPNK3 was determined by performing a multiple alignment of the sequencing data with sequences of related Bacillus spp. (GenBank database of the National Center for Biotechnology Information, www.ncbi.nlm. nih.gov/GenBank/) using ClustalW (Thompson et al., 1994). The tree was constructed using the neighborjoining method of Saitou and Nei (1987) in combination with the bootstrap method (Felsenstein, 1985). The $16 \mathrm{~S}$ rRNA gene sequence obtained was deposited in GenBank under accession number: FJ748503

The sequencing of the $16 \mathrm{~S}$ rRNA gene of TPNK3 strain allowed us to determine the sequence of approximately $90 \%$ of the complete gene. The $16 \mathrm{~S}$ rDNA phylogenetic tree (Fig. 1) indicated that isolate TPNK3 clusters together with the strains that are classified to genus Bacillus, sharing $>99.9 \%$ sequence similarity with 16S rDNA sequences of of Bacillus gelatini strain TMW 2.552 (GenBank Accession No. AJ809500), Bacillus gelatini strain R-13822 (GenBank Accession No. AJ586347), and $98.30 \%$ sequence similarity with Bacillus gelatini strain 506 (GenBank accession No. DQ350818). Based on this high sequence similarity to Bacillus gelatini members, isolate TPNK3 may be tentatively described as Bacillus gelatini strain TPNK3. However, it is assumed that organisms showing greater than $97 \% 16 \mathrm{~S}$ rDNA sequence similarity are likely to have $70 \%$ or more DNA-DNA relatedness and thus can be considered to be the same species (Nazina et al., 2001). Nevertheless, in accordance to the rules of taxonomy, the proper classification of bacteria to the species requires to determine the degree of DNA-DNA hybridization. So far described Bacillus gelatini strains are mesophilic and therefore the isolation of a thermophilic strain points to the heterogencity of member of the genus Bacillus. Therefore it is 


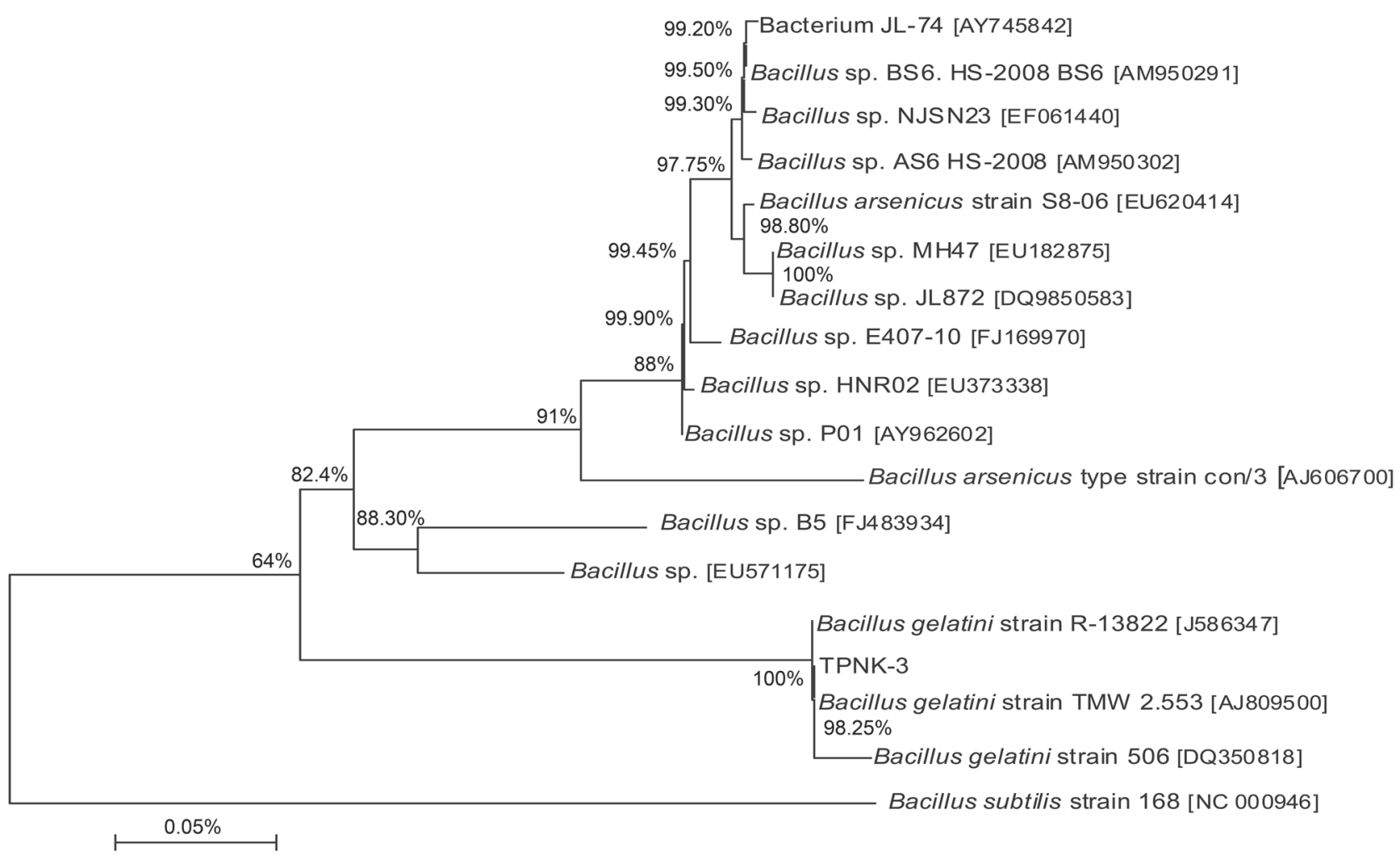

Fig. 1. Neighbor-joining tree showing the phylogenetic affiliation of isolate TPNK3 with selected members of Bacillus spp., with Bacillus subtilis strain 168 included as an out-group. Bootstrap values greater than $50 \%$ are indicated.

The scale bar represents $0.05 \%$ of the estimated substitutions per nucleotide position

necessary to underline that TPNK3 strain is the first thermophilic Bacillus gelatini strain described.

In addition, the mol \% $\mathrm{G}+\mathrm{C}$ of isolate TPNK3 of $45 \%$, was also in the range found for Bacillus gelatini strains (De Clerck et al., 2004; Yoon et al., 2005) and Anoxybacillus contaminans sp. (De Clerck et al., 2004).

In order to establish the morphology of TPNK 3 strain, cells were stained with Gram stain and studied under the microscope (Olympus, LH50A, Tokyo, Japan) and image captured using a TTL Auto-exposure $35 \mathrm{~mm}$ SLR camera (Olympus SC35 Type 12, Tokyo, Japan) at a magnification of $x 1000$. Cell size was estimated using a calibrated eyepiece, and was an average of 10 measurements of distinct cells. Cells were Grampositive, rod-shaped ( $3.28 \mu \mathrm{m}$ long and $0.45 \mu \mathrm{m}$ wide), and form spherical terminal spores (Fig. 2). The ability of the TPNK3 to utilize various polymeric substrates was studied by its capacity to secrete extracellular enzymes: protease (s), amylase (s) and cellulose (s) enzymes (Table I). Furthermore, the isolate could utilize several carbon and nitrogen sources (Table I) indicating its heterotrophic growth pattern (Stackebrandt and Geobel, 1994), characteristic of members of the genus Bacillus and related genera.

Endospore-forming aerobic bacterial species such as Bacillus sp., among others, are ubiquitous and have been isolated from a variety of habitats ranging from very cold to extremely hot. Bacillus sp. are very successful in colonizing various habitats, and are often tested in search of valuable bioproducts, such as enzymes,

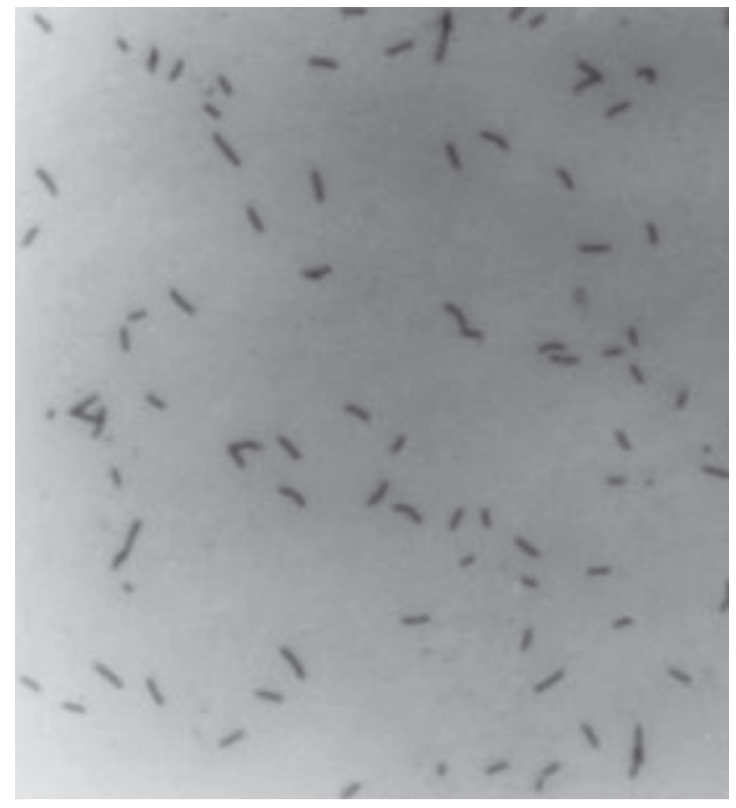

Fig. 2. Micrograph presents typical cell morphology of $6 \mathrm{hr}$ culture of TPNK3 in standard broth medium. A camera (Olympus SC 35 typer 12 Tokyo, Japan) mounted on a phase contrast microscope (Olympus LH 50A, Tokyo, Japan) was used to take this photomicrograph. The magnification used was X 1000 
Table I

Growth characteristics of isolate TPNK3

\begin{tabular}{|c|c|}
\hline Test parameter & Result \\
\hline Temperature range of growth $\left({ }^{\circ} \mathrm{C}\right)$ & $40-60$ \\
\hline pH growth range & $5-8$ \\
\hline Growth in $\mathrm{NaCl}(\%)$ & $0-7$ \\
\hline Indole & + \\
\hline Mo $1 \% \mathrm{G}+\mathrm{C}$ & 45 \\
\hline Catalase & + \\
\hline Temperature range of growth $\left({ }^{\circ} \mathrm{C}\right)$ & $40-60$ \\
\hline $\mathrm{pH}$ growth range & $5-8$ \\
\hline Growth in $\mathrm{NaCl}(\%)$ & $0-7$ \\
\hline \multicolumn{2}{|l|}{ Carbon utilization with acid production } \\
\hline L (-) Sorbos & + \\
\hline Sorbital & + \\
\hline L (+) Arabinose & + \\
\hline B-D (-) Fructose & + \\
\hline D (-) Arabinose & + \\
\hline D (+) Xylose & + \\
\hline Inulin & + \\
\hline D (+) Maltose & + \\
\hline d-Mannitol & - \\
\hline Cellulose & + \\
\hline $\mathrm{D}(+)$ Galactose & + \\
\hline Dextrin & + \\
\hline I Inosital & - \\
\hline Cellobiose & - \\
\hline $\mathrm{D}(+)$ Glucose & + \\
\hline Starch & + \\
\hline Sodium acetate & - \\
\hline Sodium malonate & - \\
\hline Sodium oxalate & - \\
\hline Sodium succinate & - \\
\hline Sodium malate & + \\
\hline \multicolumn{2}{|l|}{ Nitrogen utilization } \\
\hline DL-Serine & + \\
\hline L-Asparagine & - \\
\hline DL-Phenylalanine & + \\
\hline DL-Valine & + \\
\hline L-Glutamate & + \\
\hline L-Arganine & + \\
\hline DL-Tyrosine & - \\
\hline L-Cystein & + \\
\hline \multicolumn{2}{|l|}{ Glycine } \\
\hline L-Aspartic acid & - \\
\hline L-Tryptophan & + \\
\hline L-Arginine & - \\
\hline DL-Histidine & - \\
\hline D-Alanine & + \\
\hline D-Methionine & + \\
\hline DL-Leucine & + \\
\hline L-Tyrosine & - \\
\hline Urea & - \\
\hline DL-Ornithine & + \\
\hline
\end{tabular}

Key: $+=$ positive, $-=$ negative, $\mathrm{N}=$ not determined for application in industry and other biotechnological operations. Hot and other extreme environments are considered the most valuable sources of organisms that produce enzymes that can be used in industrial processes. In this study, protease-secreting thermophilic bacteria were isolated from compost heaps from Kiteezi landfill of Kampala City Council. Since there is a strong interest in the utilization of thermostable enzymes, TPNK3 strain can be a valuable source of novel proteolytic enzyme (s) that could be utilized in various biotechnological processes.

\section{Acknowledgments}

This work was supported through a grant provided by the International Foundation for Science (IFS) and the Council for the Development of Social Science Research in Africa (CODESRIA). We also thank Kampala City Council for providing us permission to use Kiteezi Landfill as a sampling site.

\section{References}

De Clerck E., M. Rodríguez-Díaz, T. Vanhoutte, J. Heyrman, N.A. Logan and P. De Vos. 2004. Anoxybacillus contaminans sp. nov. and Bacillus gelatini sp. nov., isolated from contaminated gelatin batches. Int. J. Syst. Evol. Micro. 54: 941-946.

Felsenstein J. 1985. Confidence limits on phylogenies: An approach using the bootstrap. Evolution, 39: 783-791.

Genckal H. and C. Tari. 2006. Alkaline protease production from alkalophilic Bacillus sp. isolated from natural habitats. Enzyme Microb. Technol., 39: 703-710.

Hawumba J.F., J. Theron and V.S. Brözel. 2001. Thermophilic protease-producing Geobacillus from Buranga hot springs in western Uganda. Curr. Microbiol. 45: 144-150.

Jaenicke R., H. Schurig, N. Beaucamp and R. Ostendorp. 1996. Structure and stability of hyperstable proteins: Glycolytic enzymes from hyperthermophilic bacterium Thermotoga maritima. Adv. Prot. Chem. 48: 181-296.

Ki J-S., W. Zhang and P.-W. Qian. 2009. Discovery of marine Bacillus species by $16 \mathrm{~S}$ rRNA and $\mathrm{rpoB}$ comparisons and their usefulness for species identification. J. Microbiol. Meth. 77: 48-57.

Liu Z., J. Luo, Q. Bai, M. Ma, G. Guan and H. Yin. 2005. Amplification of $16 \mathrm{~S}$ rRNA genes of Anaplasma species in China for phylogenetic analysis. Vet. Microbiol. 107: 145-148.

Liu S., N. Zhu., L.Y. Li and H. Yuan. 2011. Isolation, identification and utilization of thermophilic strainsin aerobic digestion of sewage sludge. Water Research, 45: 5959-5968

Mei Y., Bingfang He, N. Liu and P. Ouyang. 2009. Screening and distributing features of bacteria with hydantoinase and carbamoylase. Microbiol. Res. 164: 322-329.

Nazina N.T., P.T. Tourova, B.A. Poltaraus, V.E. Novikova, A.A. Grigoryan, A.E. Ivanova, M.A. Lysenko, V.V. Petrunyaka, A.G. Ospov, S.S. Belyaev and V.M. Ivanov. 2001. Taxonomic study of aerobic thermophilic bacilli: Descriptions of Geobacillus subterraneus gen. nov., sp. nov. and Geobacillus uzenensis sp. nov. from petroleum reservoirs and transfer of Bacillus stearothermophilus, Bacillus thermocatenulatus, Bacillus thermoleovorans, Bacillus kaustrophilus, Bacillus thermoglucosidasius and Bacillus thermodenitrificans to Geobacillus as the new combinations G. stearothermophilus, G. thermocatenulatus, G. thermoleovorans, G. kaustrophilus, G. ther- 
moglucosidasius and G. thermodenitrificans". Int. J. Syst. Evol. Micr. 51: 433-446.

Nogales B., E.R.B. Moore, E. Llobet-Brossa, R . Rossello-Mora, R. Amann and K.N. Timmis. 2001. Combined use of $16 \mathrm{~S}$ ribosomal DNA and 16S rRNA to study the bacterial community of polychlorinated biphenyl-polluted soil. Appl. Environ. Microbiol. 67: 1874-1884.

Owen R.J. and L.R. Hill. 1979. The estimation of base compositions, base pairing and genome size of bacterial deoxyribonucleic acids pp. 277-296. In: Skinner F.A. and W. Lovelock D. (Ed), Identification Methods for Microbiologists, $2^{\text {nd }}$ edn. Academic Press, London. Saitou N. and M. Nei. 1987. The neighbor-joining method: A new method for reconstructing phylogenetic trees. Mol. Biol. Evol. 4 : 406-425.

Siarkou I.V., E.M. Mylonakis, E. Bourtzi-Hatzopoulou and F.A. Koutinas. 2007. Sequence and phylogenetic analysis of the $16 \mathrm{~S}$
rRNA gene of Ehrlichia canis strains in dogs with clinical monocytic ehrlichiosis. Vet. Microbiol. 125: 304-312.

Stackebrandt E. and B.M. Goebel. 1994. Taxonomic note: A place for DNA-DNA reassociation and 16S rRNA sequence analysis in the present species definition in bacteriology. Int. J. Syst. Bacteriol. 44: 846-849.

Thompson J.D., D.G. Higgins and T. J. Gibson 1994. CLUSTAL $\mathrm{W}$ : improving the sensitivity of progressive multiple sequence alignment through sequence weighting, position-specific gap penalties and weight matrix choice. Nucleic. Acids Res. 22: 4673-4680.

Weisburg W.G., S.M. Barns, D.A Pelletier and D.J Lane. 1991. 16S Ribosomal DNA amplification for phylogenetic study. J. Bacteriol. 173: 697-703.

Yoon J., C. Lee and T. Oh. 2005. Bacillus cibi sp. nov., isolated from jeotgal, a traditional Korean fermented seafood. Int. J. Syst. Evol. Micr. 55, 733-736. 